\title{
Reproductive biology of a bromeligenous frog endemic to the Atlantic Forest: Aparasphenodon arapapa Pimenta, Napoli and Haddad, 2009 (Anura: Hylidae)
}

\author{
AMANDA S.F. LANTYER-SILVA ${ }^{1}$, MIRCO SOLÉ ${ }^{1}$ and JULIANA ZINA ${ }^{2}$ \\ ${ }^{1}$ Programa de Pós-Graduação em Ecologia e Conservação da Biodiversidade, \\ Universidade Estadual de Santa Cruz/UESC, Rodovia Jorge Amado, Km 16, 45662-900 Ilhéus, BA, Brasil \\ ${ }^{2}$ Laboratório de Vertebrados, Departamento de Ciências Biológicas, Universidade Estadual do Sudoeste da Bahia/UESB, \\ Rua José Moreira Sobrinho, Jequiezinho, 45206-190 Jequié, BA, Brasil
}

Manuscript received on December 17, 2013; accepted for publication on March 14, 2014

\begin{abstract}
The genus Aparasphenodon is restricted to South America and comprises five poorly studied species which present a straight relationship with bromeliads. Herein we present the reproductive biology of the species Aparasphenodon arapapa. Our observations indicate that A. arapapa is a prolonged breeder, reproducing throughout the year using bromeliads as a calling and breeding site. The tadpoles complete their development inside those plants. Males, females and juveniles may also use the bromeliads as a shelter. We also describe the courtship behavior and the parental care of the species with an evidence of temporary fidelity between male and female and propose a new reproductive mode.
\end{abstract}

Key words: reproductive mode, oophagy, parental care, bromeliad.

\section{INTRODUCTION}

Although new species of frogs are continually described, with about more than 100 names being proposed worldwide each year (Köhler et al. 2005), information on the natural history for this newly described taxa is seldom provided. Even for taxa known for a long time, only recently has information become available (e.g. Silva and Juncá 2006, Ruas et al. 2012, Dias et al. 2012). Nevertheless, studies on natural history are especially important and relevant to understand interactions between individuals and their environment, being useful for conservation action plans and phylogenetic studies (Wells 2007, GomezMestre et al. 2012). Species exhibiting specialized reproduction, including complex courtship, use

Correspondence to: Mirco Solé

E-mail:msole@uesc.br of alternative reproductive sites and specialized reproductive modes, are still understudied even though they could present sets of novel adaptations associated to the taxon occurrence in its habitat in such a narrow sense, that conservation issues may have to take this information into account. One of the factors that can be pointed out as a justification for the very few natural history studies of these species is their low representativity in anuran communities. Among these anuran breeder specialists are the phytotelm-breeders (phyto=plant, telmos=ponds) that depend on waterfilled plants or plant parts. They exhibit the most complex adaptations to reproduce in these plants (e.g. complex arrangements of parental care, see GomezMestre et al. 2012).

Although comprehension of the evolutionary mechanisms that explain the association between 
frogs and plants has not been fully achieved, a better picture has just been acquired (Gomez-Mestre et al. 2012, Lehtinen et al. 2004, Brown et al. 2010). It is known that phytotelm-breeders had to improve their adaptations to phytotelmata constraints, such as low dissolved oxygen levels, risk of desiccation, and unpredictable food availability (Lehtinen et al. 2004). Additionally, competition may be stronger intra-specifically (Lehtinen 2004, Lin et al. 2008) and predation pressure less intense within units of phytotelmata when compared to larger water bodies (Kitching 2001).

Bromeliads are the most conspicuous phytotelmata in the coastal regions in Brazil. For some anuran species that use bromeliads as microhabitats, adaptations have been observed: small clutch size (e.g. Ranitomeya biolat, von May et al. 2009), endotrophic tadpoles (e.g. Syncope antenori, Krügel and Richter 1995), oophagy (e.g. Osteopilus brunneus, Lannoo et al. 1987), cannibalistic larvae (e.g. Ranitomeya ventrimaculata, Summers 1999), split clutch (e.g. Scinax perpusillus, Alves-Silva and Silva 2009), and parental care (e.g. Dendrobates pumilio, Weygoldt 1980). Among bromeliaddwellers, some species exhibit morphological adaptations for the use of this microhabitat, such as species of the genus Aparasphenodon that present a hyper-ossified cranium (Mertens 1950, Pombal 1993, Mesquita et al. 2004), useful for reducing water loss by evaporation through phragmotic behavior, a mechanism of sealing the bromeliad with its head (Andrade and Abe 1997).

The genus Aparasphenodon comprises five species (A. arapapa, A. bokermanni, A. brunoi, A. pomba and $A$. venezolanus), distributed along the coastal region of Brazil (Bahia to Santa Catarina) and upper Orinoco basin of Venezuela and Colombia (Mollo Neto and Teixeira 2012, Frost 2014). Only a few studies have addressed aspects of the natural history of species of this genus. Aparasphenodon brunoi and Aparasphenodon bokermanni have been recorded in community studies and some ecological and physiological aspects were documented (Mesquita et al. 2004, Teixeira et al. 2002, Bertoluci et al. 2007, Vilela et al. 2011). Aparasphenodon arapapa is considered a bromelicolous anuran that inhabits only "restinga" areas (Pimenta et al. 2009). The advertisement call and tadpole of this species have been recently described (Lourenço-de-Moraes et al. 2013). Herein, we present the habitat use and some reproductive aspects of Aparasphenodon arapapa including courtship behavior. Because of its specialized and stereotyped behavior in comparison with what is known for a large set of anuran species, we also describe a new reproductive mode for hylid frogs in this study, and propose its recognition.

\section{MATERIALS AND METHODS}

STUDY AREA

Our study was conducted in the Boa União Reserve $\left(15^{\circ} 04^{\prime} \mathrm{S}, 39^{\circ} 03^{\prime} \mathrm{W}, 95 \mathrm{~m}\right.$ a.s.1.) located in the municipality of Ilhéus, southern Bahia, Brazil. The area is composed by the less known phytophysignomy of the Atlantic Forest domain, called Mussununga Forest, in which vegetational traits resemble sandy coastal plains of arboreal 'restingas' (short trees and sandy soil) (sensu Thomas 2003) (Figure 1). The local climate is tropical wet (Af, according to Köppen 1936); warm and humid with no defined dry season.

\section{DATA COLLECTION AND DATA ANALYSIS}

From November 2011 to October 2012, we visited the reserve on a weekly basis (with just a few deviations of this frequency of visits). Individuals were sampled by visual and auditory search along a $300 \mathrm{~m}$ long trail. Observations began after sunset (approximately 18:00h) and finished with the end of male vocal activities at about 24:00h. Focal animal and all occurrence samplings were adopted for behavioral records (Altmann 1974).

Males were recognized by their calling activity or by their position during amplexus, because the 


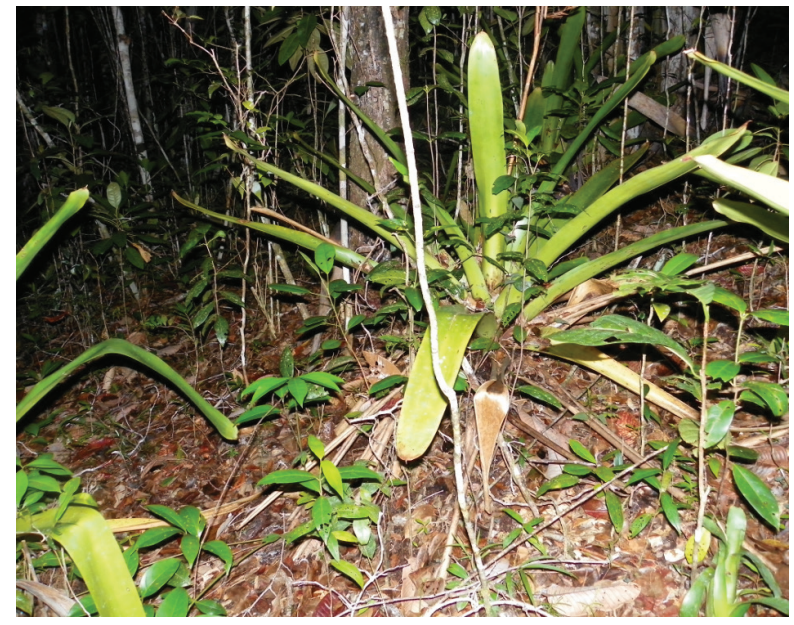

Figure 1 - The study area of Aparasphenodon arapapa at the municipality of Ilhéus, state of Bahia, Brazil.

vocal sac was undistinguishable. Females were recognized by visual inspection and detection of oocytes (when gravid) and also by their position during amplexus. We recorded the highest number of males in calling activity at one point of the trail at least twice on each field trip, between 18:00h and 24:00h. All individuals we found were measured (with a caliper of $0.01 \mathrm{~cm}$ precision) and weighed (with a field scale of $0.1 \mathrm{~g}$ precision). We followed Waichman (1992) for toe-clipping and individuals were released at the same site where they were found. Operational Sex Ratio was the mean of the number of females divided by number of males each day (Elmberg 1990). To test the null hypothesis of no difference on the snout-vent length (SVL) and body mass between males and females, we conducted a Mann-Whitney test. Mean occurrence frequency of males and females by night were obtained by dividing the total number of individuals recorded in the area along the whole study period by the number of field trips. To verify whether the mean number of calling males per month differed along the year we applied the Kruskal-Wallis test. To evaluate whether male calling activity was associated to each environmental variable (rainfall, temperature, humidity), we used the Spearman Correlation test. Temperature and humidity maximum values were recorded with a thermohygrometer at least twice during each field trip. We obtained rainfall data from a local station in the nearest municipality Una, about $22 \mathrm{~km}$ distant from the study area (except for November, December 2011 and October 2012 which were not considered in the analysis). We carried out statistical analyses using R Core Team for Windows version 2.15.2 (2012) and a significance level of 5\% to reject null hypotheses.

In order to survey the number of eggs in a clutch, we collected two clutches. Twenty-four eggs were measured (with calipers with 0.01 $\mathrm{cm}$ precision) from three different clutches. We followed the development of tadpoles of $A$. arapapa in one bromeliad and to facilitate observations in field we categorized them using the development stages of Gosner (1960), into: early (19 to 30), intermediate (30 to 36 ) and advanced (37 to 46). Ovarian follicles of two females were observed. Two males and two females were collected as voucher specimens and deposited in the Zoological Collection of Universidade Estadual de Santa Cruz - Herpetological section (adults: MZUESC 1108411089/ tadpoles: MZUESC 9097-98; 10354) under the collection permit provided by Instituto Chico Mendes de Conservação da Biodiversidade (ICMBio) to MS (13708-1).

\section{RESULTS}

\section{ADULTS}

Males of Aparasphenodon arapapa had a mean $\mathrm{SVL}$ of $45.4 \mathrm{~mm}(\mathrm{SD}=2 \mathrm{~mm}$; range=41.2-50.2 mm; $\mathrm{n}=73)$ and a mean body mass of $3.62 \mathrm{~g}(\mathrm{SD}=4.3 \mathrm{~g}$; range=2.6-4.5 g; $n=73$ ); females had a mean SVL of $53.3 \mathrm{~mm}(\mathrm{SD}=2.4$; range $=50.0-60.0 \mathrm{~mm} ; \mathrm{n}=23)$ and a mean body mass of $5.5 \mathrm{~g}(\mathrm{SD}=0.75$; range $=4.0-7.0$ $\mathrm{g} ; \mathrm{n}=23)$. There was a significant difference of SVL between the sexes $(\mathrm{W}=1679$, $\mathrm{p}$-value $<0.001)$ and body mass $(\mathrm{W}=1657.5, \mathrm{p}$-value $<0.001)$.

EGGS AND TADPOLES

Over the studied period, we recorded 34 bromeliads with tadpoles and 11 with $A$. arapapa eggs. Tadpoles 
and eggs recorded in the study period are presented in Table S1 (Supplementary material). At least 64.7\% of bromeliads that contained tadpoles and $66.7 \%$ of bromeliads that contained eggs were also occupied exclusively by a male of $A$. arapapa. We observed that tadpoles ate eggs until advanced stages of development (Figure 2). We also found tadpoles in different stages in the same bromeliads. The animal pole color of the eggs was dark gray with diameter varying from 0.50 to $0.97 \mathrm{~mm}$ (mean \pm SD: $0.78 \pm 0.14 ; \mathrm{N}=24$ ). Ovarian follicles of two females presented oocytes in different stages of maturity.

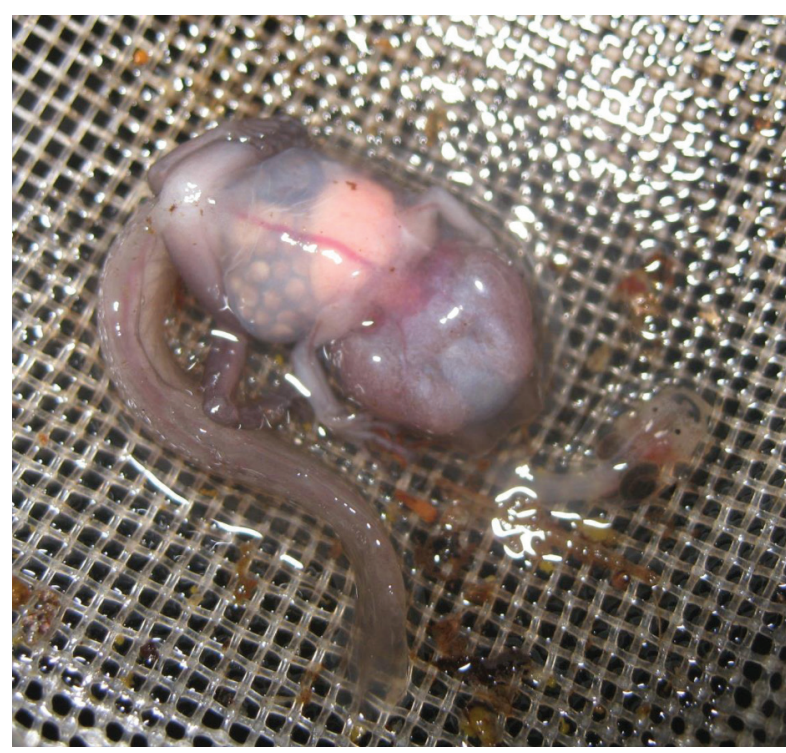

Figure 2 - Metamorph of Aparasphenodon arapapa with eggs inside digestive system; in Mussununga vegetation of southern Atlantic Forest of Bahia, municipality of Ilhéus, Brazil.

In the first attempts to follow the development of tadpoles inside bromeliads, we tried removing the tadpoles and adults to perform measurements and identify the adult individuals. However, when a bromeliad was disturbed, the male inside it always dived, hiding the tadpoles beneath it, blocking their passage to the top, making the process to access individuals much more difficult. In addition, this method probably affected the permanence of adults in the bromeliads and must have consequently affected tadpole survivorship, since on the third visit using this method, we no longer found tadpoles or adults to record. Hence, we decided to just visually count the number of individuals, intervening only for an initial identification of the adults that were in the bromeliad.

On September $13^{\text {th }} 2012$, we observed a bromeliad with a male. Five days later, we went back and found tadpoles in it (having just over $20 \mathrm{~mm}$ of total length) in the early stages of development. Ten days after that, we revisited the bromeliad and there were three tadpoles in similar early stages (approximately $30 \mathrm{~mm}$ total length). We revisited the bromeliad during four more fields surveys $(9 / 30,10 / 03,10 / 17,10 / 21)$. On the penultimate visit, the same male and also a female were recorded in courtship. After oviposition, as soon as the female left the bromeliad (the moment when we collected it for identification), we observed that the tadpoles (intermediate Gosner's stages) had eaten the eggs. On the last visit, we recorded the male and there were only two tadpoles in advanced Gosner's stages.

Habitat USE, Population DyNAMICS, AND REPRODUCTIVE ACTIVITY

We recorded males calling and sheltering only inside bromeliads, mostly in the central tank and rarely in lateral axils. They were also found perched in branches next to bromeliads, not in calling activity. Females $(n=17)$ and juveniles $(n=21)$ were also found perched in adjacent vegetation between $24 \mathrm{~cm}$ and $1.60 \mathrm{~m}$ from the ground (this highest record corresponds to a female found perched on a trunk). A female recorded on a branch, after being accidentally disturbed, was observed sheltering inside a large bromeliad full of debris. Some juveniles were seen inside epiphytic small bromeliads.

We observed individuals of other species (Phyllodytes tuberculosus, Bokermannohyla lucianae, Pristimantis sp.) and a few $A$. arapapa males (n=3) in calling activity inside bromeliads previously sampled and tagged for another individual of $A$. 
arapapa. We did not observe agonistic interactions between A. arapapa and other species. Tadpoles of other species were not recorded in bromeliads with A. arapapa tadpoles.

We marked 80 males, 46 of which were recaptured at least once in calling activity. A few males $(n=6)$ were found in the same bromeliad where they had already been captured days or months earlier (Table I). Twenty-one females were marked and four were recaptured. We could not access displacement of females, since most were found perched on branches, not inside a bromeliad (that we had been marking and monitoring). For 11 recaptured males it was possible to access their displacement between bromeliads used as calling sites. The mean distance between bromeliads used by the same males was $3.27 \mathrm{~m} \pm 3.62 \mathrm{~m}(\mathrm{n}=16$; range $=0.45-12 \mathrm{~m}$ ). Individual male distance of displacement between bromeliads and the time interval between captures are presented in Table II.

\section{TABLE I}

Males of Aparasphenodon arapapa recaptured in the same bromeliad in a Mussununga of the Southern Atlantic Forest of Bahia, municipality of Ilhéus, Brazil.

\begin{tabular}{ccc}
\hline Male & Bromeliad & $\begin{array}{c}\text { Interval between } \\
\text { recapture (days) }\end{array}$ \\
\hline A & 1 & 23 \\
B & 2 & 251 \\
C & 3 & 160 \\
D & 4 & 133 \\
E & 5 & 12 \\
F & 6 & 42 \\
\hline
\end{tabular}

The longest distance recorded between males in vocal interaction was $8.30 \mathrm{~m}$ and the shortest was $0.59 \mathrm{~m}$. No satellite males were observed. However, on one occasion, we recorded two previously marked A. arapapa males in the same bromeliad. Male 1, which was previously recorded in a bromeliad located $74 \mathrm{~cm}$ from the observed bromeliad, was in calling activity above another male (Male 2) that remained quiet. The call was very similar to the advertisement call, but it was emitted at lower note intervals.
TABLE II

Individual displacement of Aparasphendon arapapa males recorded in space and time between bromeliads used in a Mussununga of Southern Atlantic Forest of Bahia, municipality of Ilhéus, Brazil. D.I. = day interval; $\mathbf{m}=$ months; $\mathbf{d}=$ days; B1-B2 = bromeliad 1 distance to bromeliad 2 (same pattern to B2-B3 and B3-B4); Distance in meters.

\begin{tabular}{ccccccc}
\hline Male & $\begin{array}{c}\text { D.I. } \\
\text { B1-B2 }\end{array}$ & $\begin{array}{c}\text { Distance } \\
(\mathbf{m})\end{array}$ & $\begin{array}{c}\text { D.I. } \\
\text { B2-B3 }\end{array}$ & $\begin{array}{c}\text { Distance } \\
(\mathbf{m})\end{array}$ & $\begin{array}{c}\text { D.I. } \\
\text { B3-B4 }\end{array}$ & $\begin{array}{c}\text { Distance } \\
(\mathbf{m})\end{array}$ \\
\hline I & $12 \mathrm{~d}$ & 2.10 & - & - & - & - \\
II & $8 \mathrm{~m} \mathrm{1d}$ & 0.66 & - & - & - & - \\
III & $1 \mathrm{~m} 8 \mathrm{~d}$ & 1.14 & - & - & - & - \\
IV & $9 \mathrm{~d}$ & 2.26 & $1 \mathrm{~m} 20 \mathrm{~d}$ & 2.65 & $5 \mathrm{~m} \mathrm{9d}$ & 2.93 \\
V & $6 \mathrm{~m} 27 \mathrm{~d}$ & 5.03 & $1 \mathrm{~m} 6 \mathrm{~d}$ & 0.68 & $2 \mathrm{~m} \mathrm{5d}$ & 0.45 \\
VI & $7 \mathrm{~d}$ & 2.60 & $1 \mathrm{~m} 2 \mathrm{~d}$ & 3.40 & - & - \\
VII & $7 \mathrm{~d}$ & 2.80 & - & - & - & - \\
VIII & $7 \mathrm{~m} 15 \mathrm{~d}$ & 1.01 & - & - & - & - \\
IX & $10 \mathrm{~m} 8 \mathrm{~d}$ & 0.74 & - & - & - & - \\
X & $29 \mathrm{~d}$ & 12 & - & - & - & - \\
XI & $3 \mathrm{~m} \mathrm{11d}$ & 12 & - & - & - & - \\
\hline
\end{tabular}

The mean operational sex ratio was 0.21 $(\mathrm{SD}=0.38 ; \mathrm{n}=43$; range $=0-2)$. Mean frequency of occurrence of males was 2.60 individuals per night while females presented mean frequency of occurrence of 0.47 individuals per night. Individuals usually began calling between 5p.m. and $6 \mathrm{p} . \mathrm{m}$, independently of sunset. The activity peak was between 7p.m. and 9p.m (Figure 4). Males were found in calling activity throughout the year, but varied in abundance on different nights. On two nights of heavy rainfall, we observed that males did not stop calling. The number of calling males was not correlated with daily rainfall $(\mathrm{r}=-0.061 ; \mathrm{p}=0.65)$, mean daily air temperature $(\mathrm{r}=-0.146 ; \mathrm{p}=0.1721)$, or mean daily humidity $(\mathrm{r}=0.147 ; \mathrm{p}=0.17)$. Calling activity of $A$. arapapa lasted all year and there was no significant difference between the mean number of males calling per month (Kruskal-Wallis chisquared $=11 ; p=0.4433$ ). Courtships were observed in four months of the study period, while tadpoles and clutches were not recorded only in June and July 2012 (Table S1). 


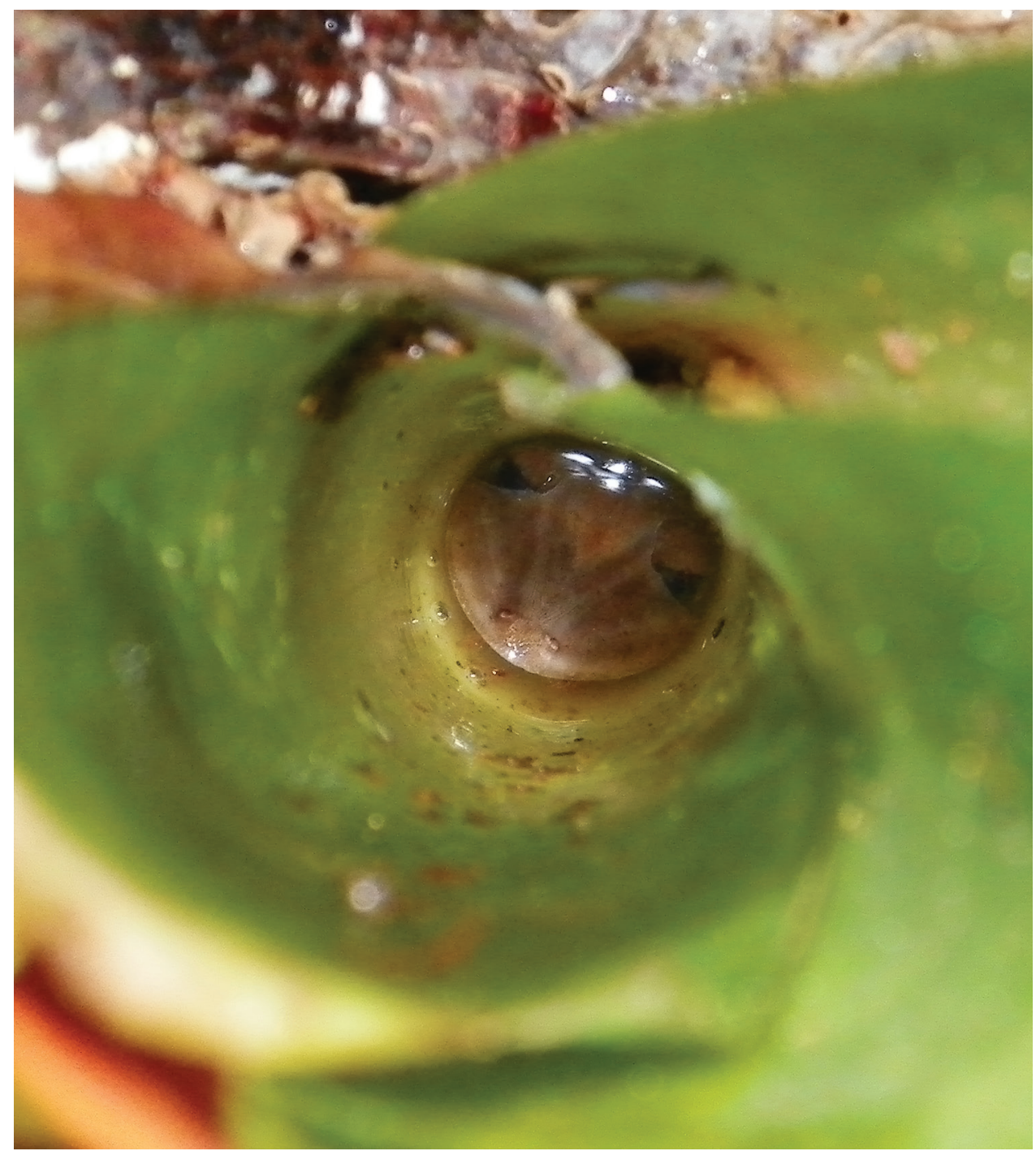

Figure 3 - Aparasphenodon arapapa male in a bromeliad, municipality of Ilhéus, Bahia Brazil.

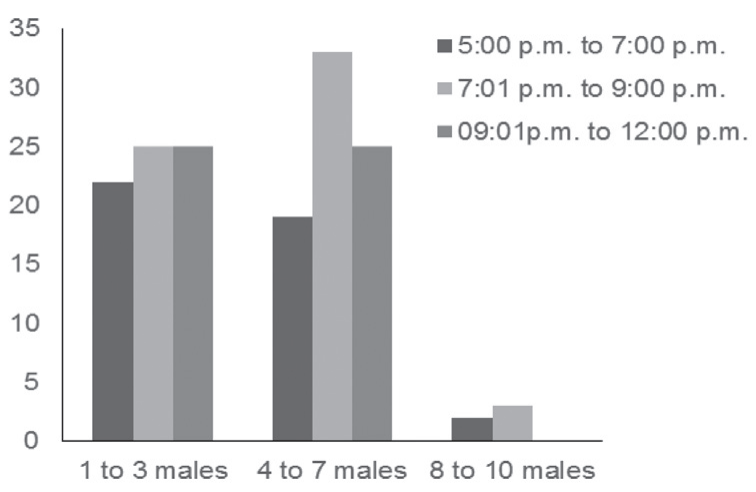

Figure 4 - Calling activity peak of Aparasphenodon arapapa males; in Mussununga vegetation of southern Atlantic Forest of Bahia, municipality of Ilhéus, Brazil.

\section{COURTSHIP AND SPAWNING}

We recorded five interactions between males and females of $A$. arapapa, all of them occurring inside the central tank of a bromeliad. We followed one courtship from beginning to end, lasting three hours, approximately. The description of the first mating recorded is given below (Figure 5):

Initially, the female was perched on one of the leaves of a bromeliad adjacent to a calling male. When she jumped to a leaf of the bromeliad in which the male was calling (Figure 5A), he stopped calling and both remained still for a few moments; 
A

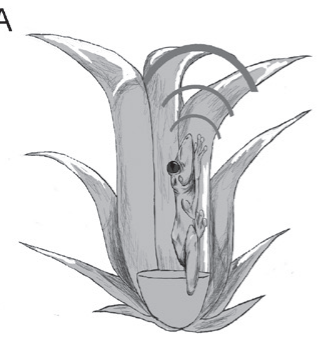

B

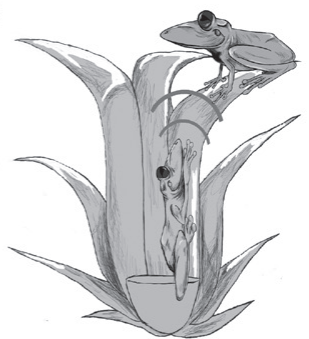

C

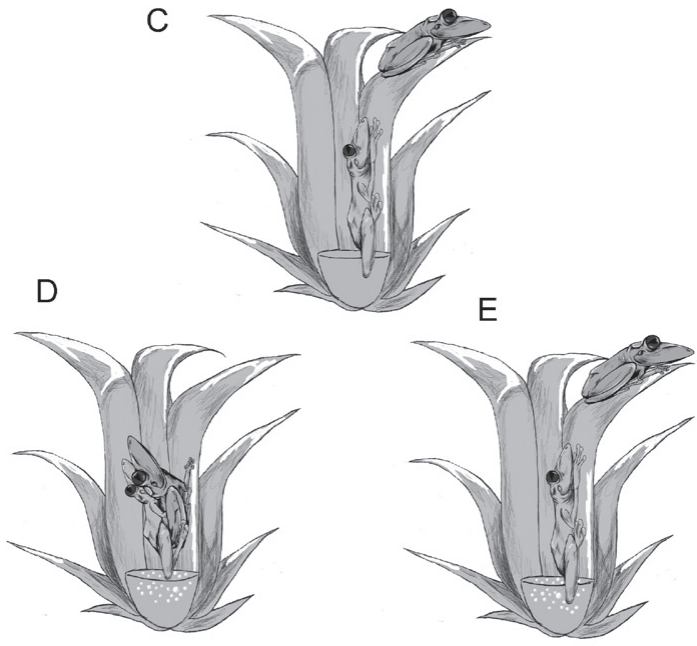

Figure 5 - Courtship of Aparasphenodon arapapa in Mussununga vegetation of southern Atlantic Forest of Bahia, municipality of Ilhéus, Brazil. (A) Calling male inside a bromeliad; (B) Female approaches; (C) Female prepares to go down to the central tank of the bromeliad; (D) Male and female in axillar amplexus. Note the concave arching of female followed by male and oviposition; (E) Female leaves the bromeliad and male remains still with eggs ovipositioned.

After this period of silence, the male returned to calling activity, emitting a very similar call to the advertisement call, but with a higher note repetition rate. The female moved backward slowly to the central tank with her head turned towards the opening of the central tank (Figure 5B);

Immediately after that, the male emitted three calls at lower intensity positioning himself behind the female with his head touching the female's head, grasping the female by the axilla, in amplexus position (Figure 5C);

After about 50 minutes, the female began performing concave arching of head and body together against the bromeliad. The male followed her movements (Figure 5D);
During the last 20 minutes, the female did at least 13 concave arching movements, the longest lasting 24 seconds and the shortest, 6 seconds; between one arching movement and another, the male emitted two low intensity calls and then the female made one more arching movement;

A few minutes later, the female moved upward, away from the male, up to the central tank of the bromeliad (Figure 5E). From that moment on, they were no longer in amplexus; the male remained inside the central tank, and after a few minutes resumed calling activity.

The female then left the bromeliad, after 35 minutes of being still and the male remained inside the bromeliad with the eggs.

From the moment they were sighted, the other four courtships showed basically the same pattern, but there was one unobserved behavior in the first courtship. In the second event, we observed that a male in amplexus with a female moved his head up and down quickly a few times, seeming as if he was hitting the female's head.

Two of the courtships that we observed partially were performed by the same couple in a very short period of time (01/24/2012 and 02/04/2012). On the first occasion, we observed the couple laying eggs inside the bromeliad. Eleven days later we returned to the same bromeliad and there were tadpoles and the same male was in the plant. Later on that day, the male was in amplexus with the same female from before. About two hours later, the tadpoles, as observed before, had eggs in theirs digestive system.

\section{DISCUSSION}

ADULTS

We found statistical difference between sexes in $A$. arapapa, females being larger than males. At least $90 \%$ of anurans present sexual dimorphism (Shine 1979) with females being larger than males. Since Charles Darwin's sexual selection theory, four 
hypotheses have been proposed to explain this morphological pattern between sexes: (1) Females are larger because this characteristic allows them to produce and store more eggs, since there is a correlation between SVL and clutch size, already observed for many anuran species (Duellman and Trueb 1994); (2) Females are larger because they live more and this allows them to grow larger (Duellman and Trueb 1994); (3) Males larger than females are a common characteristic among territorial species, since this feature increases their chances during physical combats (Lee 1986, Tsuji 2004); (4) The presence of dimorphism can be a mechanism for reducing intersexual competition for resources, such as food or shelter (see the review by Shine 1989). Since we did not find any male-male aggressive behavior and the sexual dimorphism is pronounced, the larger size of females is probably related to age or even clutch size (Duellman and Trueb 1994) associated to female parental care ("trophic eggs", see below).

\section{EGGS AND TADPOLES}

Phytotelm-breeders clutch size varies between 1 to 4,336 eggs, Ranitomeya imitator and Trachycephalus resinifictrix, respectively. Nevertheless, only seven species, out of 53, for which the clutch size is known, present more than 100 eggs per clutch (G. Moser et al. unpublished data). Clutch size of $A$. arapapa is larger than that of other phytotelm-breeders, as all species from the genera Flectonotus, Dendrobates and Phyllodytes produce less than 30 eggs per clutch (Moser et al. unpublished data). Notwithstanding, we observed, when trying to follow tadpole development, that few of them survived until metamorphosis.

Body size of tadpoles of $A$. arapapa species is large (Lourenço-de-Moraes et al. 2013) and this fact must increase competition for resources; this is probably the reason why only a few bromeliads were found with more than two tadpoles in advanced development stages. Indeed, the reduction of the number of tadpoles was observed to be in early stages however we do not know the mortality rates. Ranitomeya ventrimaculata, mostly in Heliconia pools, independent of the number of tadpoles deposited, end with only one tadpole that survives through a cannibalism strategy (Summers 1999). Teixeira et al. (2006) estimated that approximately $92.4 \%$ of Scinax perpusillus tadpoles in a saxicolous community of bromeliads would not survive until adulthood. The most likely cause of these high mortality rates indicated by the authors was predation. For $A$. arapapa, as well as for other phytotelmata breeders, predation would hardly be a selective pressure in this environment, since predation is relatively low in phytotelmata compared to other frog breeding sites (Kitching 2001, Summers 1999). Additionally, why would a predator choose to eat only some tadpoles and not all of them? The buccal morphology of tadpoles does not support another possibility: cannibalism (Lourençode-Moraes et al. 2013) once the froglets show the same buccal morphology as during the larval phase (personal observation). Therefore, the most likely hypothesis that explains the higher tadpole mortality would be a shortage of food, evidenced by parental care to provide eggs as food for tadpoles (Lourençode-Moraes et al. 2013). Therefore, we recommend further studies on diet of $A$. arapapa tadpoles since it is of fundamental importance to understand the mortality rates of tadpoles in order to determine the reproductive success of individuals and comprehend population dynamics.

Egg size is known as a more conservative reproductive characteristic that varies relatively little among congeneric species when compared to clutch size (Duellman and Trueb 1994). However, information on egg size from other Aparasphenodon species is not available. When compared to Osteocephalus oophagus (Jungfer and Weygoldt 1999), another bromeligenous species with biparental care that provides eggs for their tadpoles, A. arapapa presents a smaller egg size. Summers et al. (2007) revealed a non-significant relationship 
between egg size and phytotelmata breeding, however they used a small sample size, since there is little comparative data of phytotelm anuran breeders, especially tropical ones. Concerning development rate, the Amazonian species Osteocephalus oophagus presents parental care and provides fertilized eggs (Jungfer and Weygoldt 1999) to tadpoles that become metamorphs between 27 to 50 days. Kurixalus eiffingeri exhibits parental care with unfertilized eggs provided by the female, completing their development 40 to 78 days after hatching (Lin and Kam 2008). At the same time, species that breed in temporary ponds in arid regions show rapid development which may take 13 to 18 days to metamorphosis (Duellman and Trueb 1994). A great part of hylid species present a long growth and developmental rate (Richardson 2002), despite the natural plasticity in tadpole development rate of any species due to environmental and/or intrinsic factors (Rose 2005). When we followed the development of the tadpoles inside a bromeliad, it was possible that the one in an advanced stage of development had metamorphosed before the penultimate visit. This implies that A arapapa tadpoles have a relatively short development rate and, in addition to the exotrophic food supply, this must have been fundamental for occupying this niche little explored by anurans, the phytotelmata.

\section{Habitat USE, Population Dynamics, AND REPRODUCTIVE}

\section{ACTIVITY}

Males, females and juveniles of $A$. arapapa were recorded using bromeliads as shelter and adjacent vegetation as foraging areas. We also observed this behavior in other bromeliad-breeders, such as Phyllodytes melanomystax and P. luteolus. In the study area the number of bromeliads is high and the density of $A$. arapapa males in calling activity was relatively low, when compared to other species that use other water bodies for reproduction (e.g. Phyllomedusa nordestina, Vilaça et al. 2011). At the same time, we observed a spatial segregation of the anuran community in the study area: we recorded a temporal partition of a few terrestrial bromeliads by different individuals of $A$. arapapa and other species. This occupation pattern may prevent spatial intra and interspecific competition inside terrestrial bromeliads that are more accessible than epiphytic ones to some anuran species. In fact, we did not observe tadpoles of different species in syncronopatry. However, it had been considered a possibility, since Peixoto (1995) recorded Crossodactylodes sp. and Scinax sp. larvae in the same bromeliad.

Philopatry is the tendency of some animals to return to specific locations to feed or breed (e.g. Rana sylvatica, Berven and Grudzien 1990), while territoriality is the spatial resource defense against intruders, especially intra-specific ones, expressed by vocal activity and or agonist interactions (e.g. Phyllomedusa nordestina, Vilaça et al. 2011). The displacement distances of $A$. arapapa males indicate philopatry. In fact, some individuals were recorded less than a few centimeters from the first tagged bromeliad. However, the distances of males involved in vocal interaction were sometimes shorter than expected. Also, no agonistic interactions were observed among males. Nevertheless, it is possible that the territorial area, considered by $A$. arapapa males, is just the bromeliad unit, indicated also by philopatric behavior. We have two hypotheses to explain the philopatry of $A$. arapapa concerning its bromeliad: (1) one particular bromeliad is a chosen resource among others; it is the habitat for breeding and a shelter that presents favorable features for these activities. Therefore the individual of $A$. arapapa would remain in the same location until there is a need to change, (2) A. arapapa presents parental care and the male has a territorial behavior related to one bromeliad, to make it possible for females to return to mate and feed the tadpoles.

Although we observed a reduction of calling activity from February to May, Aparasphenodon arapapa may be considered a prolonged breeder (sensu Wells 2007). Moreover, males of 
A. arapapa typically presented the behaviors of prolonged breeding anuran species (Wells 1977), using vocalization to attract females and being territorialists. Additionally, the species present a low operation sex ratio, another typical characteristic of prolonged breeding season species (Wells 2007).

A large set of tropical anuran species presents reproduction positively associated to temperature, humidity and/or rainfall (Duellman and Trueb 1994, Aichinger 1987). We expected these variables to be important for $A$. arapapa, even though it is a oneyear study and we do not have temporal replication. Nonetheless, the absence of correlation of calling activity with rainfall, humidity and temperature may be explained by the relative stability of these variables for the anuran species since (1) the microhabitat used by $A$. arapapa stores water and does not dry so easily as would a temporary water body formed by rainfall on a 'restinga' soil, (2) the proximity with the coast implies that the levels of humidity are relatively high all year round (3) the levels of temperature do not suffer abrupt changes, as observed in other Brazilian regions.

\section{COURTSHIP AND SPAWNING}

As observed by Duellman and Trueb (1994), most anurans display amplexus at or near the oviposition site. In the case of $A$. arapapa, male and female amplexus were recorded only inside bromeliads and included concave arching of females and tactile stimuli of the female's head by the male's head. The first behavior tends to be related to peristaltic abdominal contractions, moving ovules to oviducts in females, but these movements may not be perceived by a male that breeds in other water bodies. However, the amplexus of $A$. arapapa is limited by bromeliad boundaries and it is probable that males have a more accurate perception of oviposition by the female, as demonstrated by tactile stimuli of the males' head and low intensity calls during intervals between the females' concave arching body.
According to Wells (1977), females of prolonged breeders choose the males by their acoustic characteristics, which seems to be the case of $A$. arapapa. Additionally, we did not observe female inspection behavior. For Hyla femoralis, a treefrog that inhabits Pine flatwoods, experiments demonstrated that females identify habitats with and without predators and prefer to oviposit in sites with no predators (Rieger et al. 2004). In the species Phrynobatrachus guineensis, a treehole breeding frog, females inspect breeding sites before spawning (Rödel et al. 2004) a behavior also observed for Scinax perpusillus females, a bromeliad-breeder (Alves-Silva and Silva 2009). In the view of a possible shortage of suitable breeding sites (see below) and a large investment in parental care, it is possible that (1) the choice for a male is more important than the choice for an oviposition site and, therefore, the female's choice is based on "vocalization quality" (Ryan 1980), (2) the vocalization of the male within the bromeliad indicates bromeliad characteristics of interest to acoustic effect, as observed for Metaphrynella sundana males that are capable of exploiting resonance effects in tree-holes (Lardner and Lakim 2002), (3) the female mates with more than one male (polyandrous system), (4) the behavior of inspection does exist, but was not observed.

The fact that a same couple of $A$. arapapa formed on different occasions in the same bromeliad and in a short period of time, may indicate a temporary fidelity related to parental care. Only one anuran species, Ranitomeya imitator, is admittedly monogamous, an evolutionarily rare trait (Wittenberger 1980) and related to biparental care (Brown et al. 2010). Among anuran species, male parental care is typically primitive and the evolution of maternal care must have been critical to the evolution of biparental care (Summers and Earn 1999). The vast majority of sophisticated parental care in anurans is noteworthy and presented by phytotelm-breeders, such as nest 
construction, egg attendance, egg transport, tadpole attendance, tadpole transport and tadpole feeding (Lehtinen and Nussbaum 2003). Males of $A$. arapapa remain in the bromeliad with eggs and tadpoles, probably as an attendance breeding behavior. Females oviposit eggs that serve as food for tadpoles (tadpole feeding).

REPRODUCTIVE MODE

Anuran species present a great variety of reproductive modes among tetrapods (Haddad and Prado 2005, Wells 2007, Kühnel et al. 2010). Reproductive modes are a set of reproductive characteristics that include oviposition site, ovum and clutch characteristics, rate and duration of development, stage and size of hatchling, and type of parental care, if any (Salthe and Duellman 1973). It is a system of classification created by scientists that allows for discussion about reproductive features from an evolutionarily and behavioral approach. As observed by Wells (2007) the reproductive modes "(...) do not necessarily represent all the great variety of egg-laying strategies of anurans". Yet, we continuously review the list and each new set of reproductive characteristics discovered for other species must be included in the list.

Phytotelm breeding has evolved in over 100 species of anurans across a wide phylogenetic spectrum (Lehtinen et al. 2004). At least five reproductive modes are associated to phytotelmata in the last reviews of Wells (2007) and Haddad and Prado (2005). Regarding the reproductive mode of A. arapapa, it does not fit well in any of the modes. Aparasphenodon arapapa exhibits biparental care, exotrophic larvae and oviposition inside terrestrial bromeliads (lateral axils and central tank), so we suggest that reproductive mode \#6 which represents only "eggs and exotrophic tadpoles in water in tree holes or aerial plants", should be reformulated as "eggs and exotrophic tadpoles in water in phytotelmata without parental care". This new combined reproductive mode would also be interesting to classify those species that may use phytotelmata as an alternative breeding site. In addition, we propose the creation of a new reproductive mode \#40 "eggs and exotrophic tadpoles in water in phytotelmata with parental care". Parental care implies a variety of other behaviors and ecological adaptations previously described here and the population dynamics of these species is distinct from the others that present reproductive mode \#6. For now, the new mode would harbor besides A. arapapa, species like Osteopilus ocellatus, Kurixalus eiffingeri, Trachycephalus resinifictrix, and Anotheca spinosa. In this sense, all kinds of phytotelmata breeders would be contemplated.

\section{CONCLUSIONS}

Low fecundity species with high habitat specialization are most likely to suffer with populations declines (Bielby et al. 2006). Furthermore, additional attention has been dedicated to specific reproductive modes since they respond differently to habitat disturbance and deserve a different conservation approach. As pointed out by Loyola et al. (2008) and Silva et al. (2012) conservation assessments for the Atlantic Forest should include aspects of amphibian life history. Aparasphenodon arapapa is an endemic species from the Atlantic Forest, with a specific and rare reproductive mode and its populations and conservation status deserve attention. Additionally, because of their dwelling in bromeliads, anuran species are equally vulnerable to factors that affect bromeliad conservation, such as land speculation on the coastal region of Brazil (Rocha et al. 2007).

\section{ACKNOWLEDGMENTS}

We thank Milton Agustinis de Castro for the permission to conduct the study in the reserve. Joab Santanna, Iara Jaloretto and Debora Salesde-Aquino for field help; Anne Baldisseri for reviewing the manuscript; Instituto Chico Mendes 
de Conservação da Biodiversidade (ICMBio) provided the collecting permit (13708-1). This study is part of the project "Atlas of the amphibians of southern Bahia" which has been approved by the local Animal Ethics Committee of the Universidade Estadual de Santa Cruz (number 002/12).

\section{RESUMO}

O gênero Aparasphenodon é restrito à América do Sul e abrange cinco espécies pouco estudadas que apresentam uma estreita relação com bromélias. Neste trabalho apresentamos a biologia reprodutiva da espécie Aparasphenodon arapapa. Nossas observações indicam que $A$. arapapa apresenta reprodução prolongada ao longo do ano e utiliza bromélias como sítio de vocalização e reprodução. Os girinos completam seu desenvolvimento no interior das bromélias. Machos, fêmeas e juvenis podem também utilizar essas plantas como abrigo. Também descrevemos o comportamento de corte e cuidado parental da espécie, com evidência de fidelidade temporária entre macho e fêmea. Além disso, propomos um novo modo reprodutivo.

Palavras-chave: modo reprodutivo, oofagia, cuidado parental, bromélia.

\section{REFERENCES}

AichINGer M. 1987. Annual Activity Patterns of Anurans in a Seasonal Neotropical Environment. Oecologia 71(4): 583-592.

AltManN J. 1974. Observational Study of Behavior: Sampling Methods. Behaviour 49 (3/4): 227-267.

ALVES-SILVA R AND SILVA HR. 2009. Life in Bromeliads: Reproductive Behaviour and the Monophyly of the Scinax perpusillus Species Group (Anura: Hylidae). J Nat Hist 43(3): 205-217.

ANDRADE DV AND ABE AS. 1997. Evaporative Water Loss and Oxygen Uptake in Two Casque-Headed Tree Frogs, Aparasphenodon brunoi and Corythomantis greeningi (Anura, Hylidae). Comp Biochem Physiol A 118(3): 685-689.

BERTOLUCI J, BRASSALOTI RA, RIBEIRO-JÚNIOR JW, VILELA VMFN AND SAWAKUCHI HO. 2007. Species Composition and Similarities Among Anuran Assemblages of Forest Sites in Southeastern Brazil. Sci Agric 64(4): 364-374.

BERVEN KA AND GRUDZIEN TA. 1990. Dispersal in the Wood Frog (Rana sylvatica): Implications for Genetic Population Structure. Evolution 44(8): 2047-2056.
Bielby J, Cunningham AA AND Purvis A. 2006. Taxonomic Selectivity in Amphibians: Ignorance, Geography or Biology? Anim Conserv 9: 135-143.

Brown JL, Morales V and Summers K. 2010. A Key Ecological Trait Drove the Evolution of Biparental Care and Monogamy in an Amphibian. Am Nat 175(4): 436-446.

DiAs IR, LOURENÇO-DE-MORAES R AND SOlÉ M. 2012 Description of the Advertisement Call and Morphometry of Haddadus binotatus (Spix , 1824) from a Population from Southern Bahia, Brazil. North-West J Zool 8(1): 107-111.

Duellman WE AND TRUeB L. 1994. Biology of Amphibians. Baltimore and London: The Johns Hopkins University Press, $610 \mathrm{p}$.

ElmberG J. 1990. Long-term survival, length of breeding season, and operational sex ratio in a boreal population of common frogs, Rana temporaria L. Can J Zool 68: 121-127.

Frost DR. 2014. Amphibian Species of the World: An Online Reference. American Museum of Natural History. Available: http://research.amnh.org/vz/herpetology/amphibia/. Accessed 21 January 2014.

Gomez-Mestre I, Pyron RA AND WIENS JJ. 2012. Phylogenetic Analyses Reveal Unexpected Patterns in the Evolution of Reproductive Modes in Frogs. Evolution 2012: 1-14.

GosNer KL. 1960. A Simplified Table for Staging Anuran Embryos and Larvae with Notes on Identification. Herpetologica 16(3): 183-190.

HADDAD CFB AND PRADO CPA. 2005. Reproductive Modes in Frogs and Their Unexpected Diversity in the Atlantic Forest of Brazil. Bioscience 55(3): 207-217.

JungFer KH AND WeygoldT P. 1999. Biparental Care in the Tadpole-feeding Amazonian Treefrog Osteocephalus oophagus. Amphibia-Reptilia 20(3): 235-249.

KITCHING RL. 2001. Food Webs in Phytotelmata: 'Bottom-up' and 'Top-down' Explanations for Community Structure. Annu Rev Entomol 46: 729-760.

KÖHLER J, Vieites DR, BONETT RM, Garcia FH, GLAW F, STEINKE D AND Vences M. 2005. New Amphibians and Global Conservation: A Boost in Species Discoveries in a Highly Endangered Vertebrate Group. BioScience 55(8): 693-696.

KÖPPEN W. 1936. Das geographische System Der Klimate. Berlin: Verlag von Gebrüder Borntraeger, $44 \mathrm{p}$.

KRÜGELPAND RICHTER S. 1995. Syncope antenori: a Bromeliad Breeding Frog with Free-swimming, Nonfeeding Tadpoles (Anura, Microhylidae). Copeia 4: 955-965.

KÜHNEL S, REINHARD S AND KUPFER A. 2010. Evolutionary Reproductive Morphology of Amphibians: An Overview. Bonn Zool Bull 57(2): 119-126.

LANNOO MJ, TOWNSEND DS AND WASSERSUG RJ. 1987. Larval Life in the Leaves: Arboreal Tadpole Types, with Special Attention to the Morphology, Ecology, and Behavior of the Oophagous Osteopilus brunneus. Fieldiana Zool 18: 1-31.

LARDNER B AND LAKIM MB. 2002. Tree-hole Frogs Exploit Resonance Effects. Nature 420: 475. 
LEE JC. 1986. Is the Large-male Mating Advantage in Anurans an Epiphenomenon? Oecologia 69: 207-212.

LEHTINEN RM. 2004. Testes for Competition, Cannibalism, and Priority Effects in Two Phytotelm-dwelling Tadpoles from Madagascar. Herpetologica 60(1): 1-13.

LEHTINEN RM, LANNOO MJ AND WASSERSUG RJ. 2004. Phytotelm-breeding Anurans: Past, Present and Future Research. Misc Publ Mus Zool Ecol Univ Mich 193: 1-9.

Lehtinen RM And Nussbaum RA. 2003. Parental Care: A Phylogenetic Perspective. In: JAMIESON BGM (Ed), Reproductive Biology and Phylogeny of Anura. Enfield: Science Publishers, p. 343-386.

LIN YS AND KAM YC. 2008. Nest Choice and Breeding Phenology of an Arboreal-Breeding Frog, Kurixalus eiffingeri (Rhacophoridae), in a Bamboo Forest. Zool Stud 47(2): 129-137.

LIN YS, LEHTINEN RMAND KAM YC. 2008. Time- and ContextDependent Oviposition Site Selection of a PhytotelmBreeding Frog in Relation to Habitat Characteristics and Conspecific Cues. Herpetologica 64(4): 413-421.

LOURENÇO-DE-MORAES R, LANTYER-SILVA ASF, TOLEDO LF AND SolÉ M. 2013. Tadpole, Oophagy, Advertisement Call and Geographic Distribution of Aparasphenodon arapapa Pimenta, Napoli and Haddad 2009 (Anura, Hylidae). J Herp 47(4): 575-579.

LOYOla RD, Becker CG, Kubota U, Haddad CFB, FonseCA CR AND Lewinsohn TM. 2008. Hung Out to Dry: Choice of Priority Ecoregions for Conserving Threatened Neotropical Anurans Depends on Life-history Traits. Plos One 3(5): e2120.

MAY RV, MEDINA-MÜLler M, DONNELly MA AND SUMMERS K. 2009. Breeding-site selection by the poison frog Ranitomeya biolat in Amazonian bamboo forests: an experimental approach. Can J Zool 87: 453-463.

Mertens R. 1950. Ein neuer Laubfrosch aus Venezuela. Senck biol 31(1/2): 1-3.

Mesquita DO, Costa GC AND ZATZ MG. 2004. Ecological Aspects of the Casque-headed Frog Aparasphenodon brunoi (Anura, Hylidae) in a Restinga Habitat in Southeastern Brazil. Phyllomedusa 3(1): 51-59.

Mollo Neto A AND TeixeIRA M. 2012. Checklist of the genus Aparasphenodon Miranda-Ribeiro, 1920 (Anura: Hylidae): Distribution map, and new Record from São Paulo state, Brazil. Check List 8(6): 1303-1307.

Peixoto OL. 1995. Associação De Anuros a Bromeliáceas Na Mata Atlântica. Rev Univ Rural 17(2): 75-83.

Pimenta BVS, NAPOLI MF AND HADDAD CFB. 2009. A New Species of Casque-headed Tree Frog, Genus Aparasphenodon Miranda-Ribeiro (Amphibia: Anura: Hylidae), from the Atlantic Rainforest of Southern Bahia, Brazil. Zootaxa 2123: 46-54.

Pombal JP. 1993. New Species of Aparasphenodon (Anura: Hylidae) from Southeastern Brazil. Copeia 4: 1088-1091.

R CORE TEAM. 2012. R: A language and environment for statistical computing. $\mathrm{R}$ Foundation for Statistical Computing, Vienna, Austria. ISBN 3-900051-07-0. Available: http://www.R-project.org/.
RICHARDSON JML. 2002. A Comparative Study of Phenotypic Traits Related to Resource Utilization in Anuran Communities. Evol Ecol 16: 101-122.

RIEGER JF, BINCKLEY CA AND RESETARITS JR WJ. 2004. Larval Performance and Oviposition Site Preference along a Predation Gradient. Ecology 85(8): 2094-2099.

Rocha CFD, BERGALlo HG, VAN SLUYS M, ALVES MAS AND JAMEL CE. 2007. The remnants of restinga habitats in the brazilian Atlantic Forest of Rio de Janeiro state, Brazil: Habitat loss and risk of disappearance. Rev Bras Biol 67 (2): 263-273.

RÖDEL MO, RUDOLF VHW, FROHSCHAMMER S AND LINSENMAIR KE. 2004. Life history of a West-African tree-hole breeding frog, Phrynobatrachus guineensis Guibé and Lamotte, 1961 (Amphibia: Anura: Petropedetidae). In: LEHTINEN RM (Ed), Ecology and Evolution of Phytotelm-breeding Anurans. Ann Arbor: Misc Publ Mus Zool Univ Michigan 193: 31-44.

Rose CS. 2005. Integrating Ecology and Developmental Biology to Explain the Timing of Frog Metamorphosis. Trends Ecol Evol 20(3): 129-35.

Ruas DS, Mendes CVM, SzPeITer BB ANd Solé M. 2012. The Tadpole of Rhinella crucifer (Wied-Neuwied, 1821) (Amphibia: Anura: Bufonidae) from Southern Bahia, Brazil. Zootaxa 3299: 66-68.

RYAN MJ. 1980. Female Mate Choice in a Neotropical Frog. Science 209(4455): 523-525.

SALTHE SN AND DUELLMAN WE. 1973. Quantitative Constraints Associated with Reproductive Mode in Anurans. In: VIAL JL (Ed), Evolutionary Biology of Anurans. Columbia: University of Missouri, p. 229-249.

SHINE R. 1979. Sexual Selection and Sexual Dimorphism in the Amphibia. Copeia 1979(2): 297-306.

SHINE R. 1989. Ecological Causes for the Evolution of Sexual Dimorphism: A Review of the Evidence. Q Rev Biol 64(4): 419-461.

Silva FR, Almeida-Neto M, Prado VHM, Haddad CFB AND RossA-Feres DC. 2012. Humidity Levels Drive Reproductive Modes and Phylogenetic Diversity of Amphibians in the Brazilian Atlantic Forest. J Biogeogr 39(9): 1720-1732.

SILVA MB AND JUNCÁ FA. 2006. Oophagy in tadpoles of Leptodactylus troglodytes. Sitient Sér Ciênc Biol 6(2): 89-91.

SUMMERS K. 1999. The Effects of Cannibalism on Amazonian Poison Frog Egg and Tadpole Deposition and Survivorship in Heliconia Axil Pools. Oecologia 119: 557-564.

SUMMERS K AND EARN DJD. 1999. The Cost of Polygyny and the Evolution of Female Care in Poison Frogs. Biol J Linn Soc 66(4): 515-538.

Summers K, McKeon CS, Heying H, Hall J AND Patrick W. 2007. Social and Environmental Influences on Egg Size Evolution in Frogs. J Zool 271(2): 225-232.

TEIXEIRA RL, MiLi PSM AND RöDDER D. 2006. Ecology of Anurans Inhabiting Bromeliads in a Saxicolous Habitat of Southeastern Brazil. Salamandra 42(2/3): 155. 
TEIXEIRA RL, SCHINEIDER JAP AND ALMEIDA GI. 2002. The Occurrence of Amphibians in Bromeliads from a Southeastern Brazilian Restinga Habitat, with Special Reference to Aparasphenodon brunoi (Anura, Hylidae). Rev Bras Biol 62(2): 263-268.

THOMAS WW. 2003. Natural vegetation types in southern Bahia, In: PRADO PI, LANDAU EC, MOURA RT and PINTO LPS (Eds), Ilhéus: Corredor de Biodiversidade da Mata Atlântica do Sul da Bahia, p. 1-4.

TsuJI H. 2004. Reproductive Ecology and Mating Success of Male Limnonectes kuhlii, A Fanged Frog from Taiwan. Herpetologica 60(2): 155-167.

VILAÇA TRA, SILVA JRS AND SOLÉ M. 2011. Vocalization and Territorial Behaviour of Phyllomedusa nordestina Caramaschi, 2006 (Anura: Hylidae) from Southern Bahia, Brazil. J Nat Hist 45(29-30): 1823-1834.

Vilela VMFN, BRASSALOTI RA AND BERTOLUCI J. 2011 Anurofauna da Floresta de Restinga do Parque Estadual da Ilha do Cardoso, Sudeste do Brasil: Composição de Espécies e Uso de Sítios Reprodutivos. Biot Neot 11(1): 1-11.
WAICHMAN AV. 1992. An Alphanumeric Code for Toe Clipping Amphibians and Reptiles. Herpet Rev 23: 19-21.

WELLS KD. 1977. The Social Behaviour of Anuran Amphibians. Anim Behav 25: 666-693.

WELLS KD. 2007. The Ecology and Behavior of Amphibians. Chicago: University of Chicago Press, $1400 \mathrm{p}$.

Weygoldt P. 1980. Complex Brood Care and Reproductive Behaviour in Captive Poison-arrow Frogs, Dendrobates pumilio O. Schmidt. Behav Ecol Sociobiol 7(4): 329-332.

WitTENBERGER JF. 1980. The Evolution of Monogamy: Hypotheses and Evidence. Annu Rev Ecol Syst 11: 197-232.

\section{SUPPLEMENTARY MATERIAL}

Table S1 - Occurrence of eggs, tadpoles and adults inside bromeliads per months of study period. 